DOI https://doi.org/10.30525/978-9934-26-073-5-2-46

\title{
TEKST I TEKST MEDIALNY: DO KWESTII ZRÓŻNICOWANIA POJĘĆ
}

\author{
Storozhenko L. H. \\ Kandydat nauk filologicznych, profesor nadzwyczajny, \\ Profesor nadzwyczajny Dokumentacji i Działalności Informacyjnej \\ Państwowy Uniwersytet Telekomunikacji \\ Kijów, Ukraina
}

Dziś tekst rozumiany jest jako uniwersalne, podstawowe pojęcie z zakresu językoznawstwa, komunikacji, filozofii, kultury i innych dziedzin wiedzy. $\mathrm{W}$ związku $\mathrm{z}$ tym różne definicje tego pojęcia odzwierciedlają różne podejścia naukowe.

W językoznawstwie tekst jest tradycyjnie traktowany jako kompletny produkt mowy ustnej lub pisemnej, który ma wyraźną organizację strukturalno-semantyczną i komunikacyjno-semantyczną [1]. To semiotyczne podejście, ukształtowane przez klasyków F. de Saussure'a i Charlesa Pierce'a, obejmuje kilka obszarów badań nad systemami znaków i formacjami znaków: semantyką, składnią, pragmatyką. Tak więc tekst rozpatrywany jest w trzech płaszczyznach: semantyka tekstu - charakterystyka relacji między tekstem a rzeczywistością (co znajduje odzwierciedlenie w tekście, jaka jest jego treść); składnia tekstu - specyfika jego budowy wewnętrznej (cechy konstrukcji tekstu); pragmatyka tekstu - badanie «interakcji» tekstu z czytelnikiem / słuchaczem / widzem (skuteczność percepcji i zrozumienia tekstu).

Semiotyczny paradygmat naukowy rozumie tekst jako formację znakową, która jest holistycznym przekazem strukturalnym, wyrażonym za pomocą znaków i realizowanym zgodnie z regułami dowolnego systemu znakowego; jako otwarty system, który generuje i mnoży nowe znaczenia.

Z kolei dziś semiotyczna interpretacja tekstu pozostaje pod wpływem filozoficznej i kulturowej wizji naukowej.

$\mathrm{Z}$ punktu widzenia kulturologii punktem wyjścia dla pojęcia tekstu $\mathrm{W}$ kulturze jest moment, w którym sam fakt wypowiedzi językowej przestaje być dostrzegany jako wystarczający, aby wypowiedź stała się tekstem. $\mathrm{W}$ rezultacie wszystkie komunikaty językowe postrzegane są jako nietekstowe, na tle których wyróżnia się grupa «komunikatów» o charakterystycznych dodatkowych, istotnych dla danego systemu kulturowego cechach [3, s. 434-435]. 
W ujęciu filozoficznym tekst rozumiany jest jako fenomen ludzkiego świata, który wyraża się w nieustannym procesie tekstualizacji rzeczywistości. Z punktu widzenia filozofii tekst odzwierciedla rzeczywistość, którą tworzą liczne procesy, przedmioty, przedmioty, zjawiska, relacje itp., Które dopiero w procesie tekstualizacji rzeczywistości wytwarzają nowe znaczenia, wnioski, pojęcia. Taka tekstualizacja rzeczywistości jawi się jako dialog między człowiekiem a światem, esencja kultury. W szerokim sensie filozofia utożsamia tekst z całym światem, a rzeczywistość nietekstowa nie istnieje [2, s. 113].

Współczesna humanistyka krajowa aktywnie rozwija uniwersalny kierunek, który łączy różne poglądy i koncepcje - «filozofię tekstu». Tekst jest dziś podstawowym pojęciem nauk humanistycznych, stosowanym w analizie rzeczywistości jako całości. Interdyscyplinarne podejście do badania tekstu przyczynia się nie tylko do wszechstronnego badania pojęcia, ale także pozwala na tworzenie nowych definicji kategorii tekstowych.

Innym jest rozumienie tekstu medialnego. Ta koncepcja jest używana we współczesnym dziennikarstwie, komunikacji, socjologii i innych dziedzinach, aby objąć rzeczywistość. Należy zauważyć, że powstanie pojęcia «tekst medialny» jest naturalne, ponieważ obejmuje szereg różnych produktów medialnych (teksty gazet / czasopism, wiadomości radiowe, treści telewizyjne, treści internetowe itp.), Przeznaczonych do przekazywania informacji społeczeństwu i stworzyć proces komunikacji społecznej.

W związku z powyższym pojęcie «tekstu medialnego» należy rozpatrywać w kilku aspektach: badanie «tekstu medialnego» jako niezależnej jednostki naukowej; funkcjonalność pojęcia «tekst medialny»; potencjalna możliwość filozoficznej interpretacji pojęcia «tekst medialny» itp. Aby sprostać takim potrzebom naukowym, konieczne jest rozróżnienie między rozumieniem tekstu medialnego jako gotowego produktu medialnego (należącego do środowiska medialnego) $\mathrm{z}$ jednej strony, a jako procesu tekstualizacji (wpisanego w rzeczywistość medialną) na inny.

Ta segmentacja tekstu medialnego charakteryzuje się szeregiem cech, wśród których najważniejsze to: liniowość - nieliniowość; zamknięcie otwartość; struktura - formacja; zamknięty system znaków - aktywność znaków; monolog - intertekstualność.

$\mathrm{W}$ przeciwieństwie do tekstu, tekst medialny jest dziełem masowej działalności informacyjnej i masowej komunikacji, której istotą jest przekazywanie komunikatu wyrażanego w mowie, aby wpłynąć na opinię publiczną. Tekst medialny reprezentuje językową osobowość autora, jego światopogląd i światopogląd, a odbicie wydarzeń w tekście medialnym implikuje obecność w nim tzw. Ekstratekstu, swego rodzaju fragmentu wydarzeń opisywanych $\mathrm{w}$ tekście medialnym. Najważniejszą cechą 
współczesnego tekstu mass mediów, odróżniającą go od tekstu w ogóle, jest jego wielowymiarowość, którą należy rozumieć jako połączenie niejednorodnych składowych werbalnych, wizualnych, dźwiękowych lub innych $\mathrm{w}$ jednej przestrzeni semantycznej tekstu. Charakterystyczną cechą tekstów medialnych jest również ich specyfika językowa, wynikająca $\mathrm{z}$ adresowalności do masowego odbiorcy.

Pojęcie «tekstu medialnego» nie pokrywa się i nie może być tożsame $\mathrm{z}$ językową definicją «tekstu», ponieważ jego treść wykracza poza system znaków słownych, wymaga odrębnego podejścia do jego analizy. W przypadku tekstów i tekstów medialnych jedyną wspólną cechą jest obecność dużej liczby pojęć służących do definicji tych terminów.

\title{
Literatura:
}

1. Гальперин И.Р. Текст как объект лингвистического исследования. М. : Наука, 1981.

2. Деррида Ж. О грамматологии. М. : Ad Marginem, 2000.

3. Лотман Ю.М. Текст и функция. СПб.: Искусство-СПб, 2004.

DOI https://doi.org/10.30525/978-9934-26-073-5-2-47

\section{МОВНА ПОЛІТИКА В УКРАЇНІ: ДО ПРОБЛЕМИ НАЦІОНАЛЬНОЇ ЗРІЛОСТИ}

\author{
Фаріон I. Д. \\ доктор філологічних наук, доцент, \\ професор катедри украӥнської мови \\ Національного університету «Львівська політехніка» \\ м. Львів, Україна
}

Об’єктом нашого аналізу є мовна політика України президента Володимира Зеленського та його оточення.

Під мовною політикою розуміємо систему заходів, спрямованих на утвердження статусу державної мови чи інших мов, що зумовлені рівнем мовно-національної свідомости населення країни. 3 огляду на багатостолітній період (щонайменше від половини XVII століття) ліквідації та репресій щодо української мови та ії носіїв, сучасна модель мовної політики надто далека від свідчення про національну зрілість українського суспільства і іï неможливо ідентифікувати як національну модель. 